\title{
Szívinfarktus miatt kezelt betegek ellátásának vizsgálata Magyarországon a rendelkezésre álló egészségügyi adatok alapján
}

\author{
Jánosi András dr. - Póth Anikó - Zorándi Ágnes - Ofner Péter dr. \\ Gottsegen György Országos Kardiológiai Intézet, Nemzeti Szívinfarktus Regiszter, Budapest
}

\begin{abstract}
A szerzők áttekintik a szívinfarktus halálozásával kapcsolatos adatforrásokat, a Központi Statisztikai Hivatal, az Országos Egészségbiztosítási Pénztár és a Nemzeti Szívinfarktus Regiszter adatgyúijtésének fontosabb elemeit és tárgyalják az adatokból levonható következtetéseket. Megállapítják, hogy a finanszírozási adatbázis - céljának megfelelően a betegellátás során felmerülő költségek követésére, annak fedezésére alkalmas, azonban az ellátás minősége és eredményessége ezen adatbázis alapján nem ítélhető meg. A Központi Statisztikai Hivatal nemzetközi egyezmények alapján állítja össze a halálozási adatokat, amelynek alapja a halottvizsgálati bizonyítvány, amelynek korrekt kitöltése a statisztikai adatok validitásának alapfeltétele. Az infarktusos betegek ellátásának megítélése pusztán a halálozási statisztikai adatok alapján nem lehetséges. Jelenleg a hazai adatbázisok közül csak a betegregiszterek alkalmasak az ellátás minőségének és eredményességének követésére. Javasolt a szívinfarktus miatt kezelt betegek ellátásának minőség-ellenőrzésekor a Nemzeti Szívinfarktus Regiszter adatainak felhasználása. Orv. Hetil., 2016, 157(3), 89-93.
\end{abstract}

Kulcsszavak: halálozás, Nemzeti Szívinfarktus Regiszter, Központi Statisztikai Hivatal, Országos Egészségbiztosítási Pénztár, minőségbiztosítás

\section{Treatment of patients with myocardial infarction in Hungary on the basis of available health data}

The authors review data sources related to death arising from myocardial infarction, as well as the major elements of the Hungarian data collection of the Central Statistical Office, the National Health Insurance Fund and the National Registry of Myocardial Infarction. They also discuss conclusions which can be drawn from the data. It was found that the financial database - in accordance with its purpose - is suitable for monitoring the costs arising during the treatment of patient, but the quality and efficiency of treatment cannot be judged on the basis of this database. The Central Statistical Office compiles mortality data on the basis of international conventions, the basis of which is the autopsy report. However, the validity of statistical data depends on the correct completion of this report. Therefore. it is not possible to judge treatment of patients with myocardial infarction simply on the basis of mortality statistics. Considering national databases, only patient registries are suitable for monitoring the quality and efficiency of treatment currently. It is recommended that data of the National Registry of Myocardial Infarction should be used when the quality of treatment of patients with myocardial infarction is evaluated.

Keywords: mortality data, National Registry of Myocardial Infarction, Central Statistical Office, National Health Insurance Fund, quality assurance

Jánosi, A., Póth, A., Zorándi, Á., Ofner, P. [Treatment of patients with myocardial infarction in Hungary on the basis of available health data]. Orv. Hetil., 2016, 157(3), 89-93.

(Beérkezett: 2015. október 21.; elfogadva: 2015. november 12.) 


\section{Rövidítések}

AMI = heveny szívinfarktus; $\mathrm{KSH}=$ Központi Statisztikai Hivatal; NSTEMI = ST-elevációval nem járó myocardialis infarctus; NSZR = Nemzeti Szívinfarktus Regiszter; OEP = Országos Egészségbiztosítási Pénztár; PCI = percutan coronariaintervenció; $\quad$ pPCI $=$ primer percutan coronariaintervenció; STEMI = ST-elevációval járó myocardialis infarctus

A megbízható egészségügyi adatok alapvető jelentőségúek az ellátástervezés, a minőség-ellenőrzés és a tudományos munka szempontjából. A betegségek gyakoriságára, az ellátásra és annak minőségére vonatkozó hazai adatok hiánya hosszú évek óta probléma. Minden bizonnyal konszenzus van a tekintetben, hogy ez a terület - a megoldatlan finanszírozás mellett - a mindennapok legégetőbb gondja. Néhány évvel ezelőtt Gresz $[1,2]$ részletesen elemezte a finanszírozási szempontoknak megfelelően kialakított adminisztratív adatbázis problémáit, és megállapította: „... Magyarországon még egyetlen olyan egészségügyi adatbázist sem építünk, amelyből korrekt adatokat lehetne kinyerni" [1]. Mindezen ismert probléma ellenére több tanulmány alapult a finanszírozási adatokra, feltehetően abból az egyszerú tényből kiindulva, hogy csak azokat az adatokat tudjuk elemezni, amelyek rendelkezésre állnak. Legutóbb Belicza és mtsai egy nemzetközi kooperációban végzett tanulmányban [3] - amely a finanszírozási adatbázist elemezte - arra a következtetésre jutottak, hogy több területen a hazai egészségügyi ellátás minősége a legrosszabb a vizsgált országok tekintetében. Ezen adatokra hivatkozva az egyik hetilapban a szívinfarktus miatt kezelt betegekkel kapcsolatban a következőket olvashattuk: „Magyarország eredményessége a legrosszabb minden időszakban. Tragikusak az eredmények. Harminc nappal a kezelés után a magyar halálozási mutatók a legrosszabbak, mintegy 18 százalékosak. [...] ... nálunk háromszor nagyobb a veszélye, mint Norvégiában, hogy egy kórházba kerüló, ott a legmodernebb ellátást megkapó beteg meghaljon a kezelés után egy hónapon belül” [4]. Mivel ezen megállapítással kapcsolatban eltérő adatokkal rendelkezünk [5], több fórumon szóban és írásban igyekeztünk - a kétségkívül hibás - megállapításra felhívni a figyelmet. A Magyar Kardiológusok Társasága és a Nemzeti Szívinfarktus Regiszter közös közleményben foglalta össze álláspontját. A napi polémia mellett célszerúnek látszik kissé közelebbről is megvizsgálni azokat az adatokat, amelyek a szívinfarktus diagnózissal kezelt betegek halálozásával kapcsolatban rendelkezésünkre állnak.

\section{A Központi Statisztikai Hivatal adatai}

A Központi Statisztikai Hivatal (KSH) a halálozási adatok feldolgozásakor a halottvizsgálati bizonyítványon szereplő adatokból indul ki. A halál okát megállapító orvos kiállítja a hatpéldányos halottvizsgálati bizonyítványt, amelynek egy példánya elkerül a KSH-ba. A KSH illetékes munkatársai az esetek egy kis részében - ahol statisztikai szempontból kétséges az adatok megfelelősége - az adatlapot felülvizsgálatra megküldik az Állami Népegészségügyi és Tisztiorvosi Szolgálat (jelenleg a Népegészségügyi Főosztály) területileg illetékes munkatársának. Erre általában az esetek 8-10\%-ában kerül sor. Amennyiben a szóban forgó adat javításra szorul, akkor a halottvizsgálati lap többnyire visszakerül ahhoz az orvoshoz - esetleg egyéb végzettségú szakemberhez -, aki azt eredetileg kiállította, a kisebb hibákat a felülvizsgáló saját hatáskörében javítja. A javított halottvizsgálati bizonyítvány - jó esetben - ezt követően kerül vissza a KSHba. A halálok/halálokok szövegesen, a feltüntetés sorrendjében kerül/kerülnek rögzítésre. A szöveges diagnózisokhoz egy számítógépes program hozzárendeli a BNO-kódszámot. Amennyiben a halottvizsgálati bizonyítványban egy halálokot tüntettek fel, akkor az lesz az a halálok, amely a statisztikai közlésben szerepel. Több diagnózis esetén, amennyiben azok logikus oksági sorrendben vannak feltüntetve, valószínúleg az alapbetegség kerül be a statisztikába.

Kivételes esetekben, illetve ha a feltüntetett diagnózisok nem alkotnak oksági láncolatot, akkor a BNO módszertani kötetében leírt, nemzetközileg elfogadott és alkalmazott módosító szabályoknak megfelelően, úgynevezett „előztetési eljárással” egy másik halálokot választanak ki statisztikai közlésre. Például a $\mathrm{BNO}$ valamely kombinált haláloki kategóriáját jelentetik meg, mivel az több információt hordoz, vagy vannak olyan halálokok, amelyek epidemiológiai szempontból élveznek elsőbbséget. Az úgynevezett előztetési eljárás segítésére egy nemzetközileg elfogadott számítógépes programot is használnak. Az előztetési metódus célja leggyakrabban a BNO-fö́csoportokon belüli pontosítás: például amennyiben a halálokok között szerepel mondjuk krónikus ischaemiás szívbetegeség (BNO I2580) és heveny szívizominfarktus (I2100), akkor a halálozás alapokaként a heveny szívizominfarktust szerepeltetik a statisztikában. Van azonban olyan eset is, amikor ez az eljárás orvosi szempontból vitatható: például amennyiben alapbetegség a diabetes mellitus és ennek szövődményeként szívinfarktus következtében a beteg meghal, akkor a $\mathrm{BNO}$ szerint a halálozási statisztikában a cukorbetegséget kell halálokként megjelentetni, mivel az volt a halálhoz vezető betegségláncolat elindítója, és ebben az esetben módosító szabály nem érvényesíthető. Más esetben, amenynyiben a diabetes mellitus az alapbetegség és a végtagi erek szúküulete/gangraenája vezet a halálhoz, akkor a közlendő halálok a két betegség kombinációja, a diabetes mellitus keringési szöoödménnyel.

Fontos megemlíteni, hogy a halottvizsgálati bizonyítvány és a kórházak által használt fekvőbeteg-adatlap két egymástól független dokumentum, amelynek tartalma sem feltétlenül egyezik meg. A halottvizsgálati bizonyítványba a halálhoz közvetlenül vezető betegségsorozatot kell bejegyezni. Nem szükséges, sőt félrevezető olyan 
1. táblázat | Fekvóbeteg-adatlap kórházban meghalt beteg esetében

\begin{tabular}{|c|c|c|c|}
\hline 1 & Ápolást indokló fơdiagnózis alapjául szolgáló betegség & J9880 & Egyéb meghatározott légzési rendellenességek \\
\hline 3 & Ápolást indokló fódiagnózis & J9880 & Egyéb meghatározott légzési rendellenességek \\
\hline 5 & Kísérő betegség & $\mathrm{I} 2590$ & Idült ischaemiás szívbetegség, k. m. n. \\
\hline 5 & Kísérő betegség & $\mathrm{Il} 0 \mathrm{H} 0$ & Magasvérnyomás-betegség (elsődleges) \\
\hline 5 & Kísérő betegség & E8740 & A sav-bázis egyensúly kevert zavara \\
\hline 5 & Kísérő betegség & I4600 & Szívmegállás sikeres újraélesztéssel \\
\hline 6 & A halál közvetlen oka a klinikus szerint & I4690 & Szívmegállás, k. m. n. \\
\hline 7 & Kórbonctani alapbetegség & J1890 & Tüdőgyulladás, k. m. n. \\
\hline 8 & A halál közvetlen oka a kórbonctan szerint & I2190 & Heveny szívizomelhalás, k. m. n. \\
\hline 9 & Kórbonctani kísérő betegség & I7090 & Általános és k. m. n. atherosclerosis \\
\hline A & Megelőző ok a kórbonctan szerint & $\mathrm{I} 2510$ & Atheroscleroticus szívbetegség \\
\hline B & A halál alapjául szolgáló betegség a klinikus szerint & $\mathrm{I} 4690$ & Szívmegállás, k. m. n. \\
\hline
\end{tabular}

állapotok feltüntetése, amelyek közvetlenül nem játszottak szerepet a halálozásban. Összefoglalóan: alapvető jelentôségú a halottvizsgálati adatlapot kiállító orvos tevékenysége, mert ha a diagnózisok nem a megfelelő sorrendben kerülnek feltüntetésre, akkor a statisztika ami nemzetközi szabályok szerint készül - nem tükrözi/ tükrözheti a valóságot.

\section{Az Országos Egészségbiztosítási Pénztár finanszírozási adatbázisa}

Az Országos Egészségbiztosítási Pénztár (OEP) úgynevezett adminisztratív adatbázisában a járó- és fekvőbeteg-ellátás, a mentőszolgálat és a támogatott gyógyszerekkel kapcsolatos adatok kerülnek tárolásra. A fekvőbetegek ellátásáról a szolgáltatók a 49/1999-es kormányrendelet értelmében fekvőbeteg-adatlapot állítanak ki és küldik meg online módon az OEP-nek. A kórházban meghalt betegek esetén a klinikai és esetenként a kórbonctani diagnózisok szerepelnek: az ápolást indokló foodiagnózis alapjául szolgáló betegség (1), ápolást indokló fődiagnózis (3), kísérő betegség (5), a halál közvetlen oka a klinikus szerint (6), kórbonctani alapbetegség (7), a halál közvetlen oka a kórbonctan szerint (8), kórbonctani kíséró betegség (9), valamint $\mathrm{A}=$ megelőző ok a kórbonctan szerint, B = a halál alapjául szolgáló betegség a klinikus szerint. Ezen adatok megfelelőségét az OEP nem ellenőrzi, csak a finanszírozás szempontjából fontos adatok esetén van kontroll. A fentiekből következik, hogy az OEP haláloki statisztikát nem közöl, illetve nem is közölt. Egy konkrét példa szerepel az 1. táblázatban: a felsorolt diagnózisokat vizsgálva nyilvánvalóan helytelen az az értékelés, amely a halál alapjául szolgáló betegségnek a szívmegállást tekinti, hiszen ez minden halál esetén bekövetkezik, és nehezen nevezhető betegségnek. Nyilvánvaló, hogy ilyen jellegú adatszolgáltatás esetén - a konkrét eset ismerete vagy legalábbis a diagnózisok orvosi értékelése nélkül - aligha állapítható meg a halálok. Az 1. táblázatban szereplő di- agnózisok orvosi szempontú értékelése sem ad egyértelmű választ a halál okára. Az egyik lehetőség, hogy a heveny myocardialis infarctus során alkalmazott gépi lélegeztetés mellett alakult ki a pneumonia, az elektrolitzavar és a következményes szívmegállás. A másik lehetőség pedig az, hogy a pneumonia következtében alakult ki a légzési elégtelenség, a következményes hypoxia vezetett myocardialis infarctushoz, aminek kapcsán asystolia lépett fel. Az OEP feltehetően a fenti problémák miatt nem közöl hivatalos haláloki statisztikát, a kutatókra bízva a halál alapokának megállapítását.

\section{Nemzeti Szívinfarktus Regiszter}

$\mathrm{Az}$ érvényes EMMI-rendelet értelmében a Nemzeti Szívinfarktus Regiszter (NSZR) online adatbázisában 2014. január 1-je óta mindazon betegeknek szerepelniük kell, akiknél bármely egészségügyi szolgáltató heveny myocardialis infarctust (BNO I21-I23) állapított meg. A regiszter által használt adatlapon a beteg kórelőzményének és kórlefolyásának adatai szerepelnek, amelyek alapján ellenőrizhető, hogy a heveny szívinfarktus (AMI) diagnózisa megfelel-e a nemzetközileg elfogadott kritériumoknak. A számítógépes program ellenőrzi az adatok logikai kapcsolatát, illetve - a feladatra kiképzett - kontrollerek ugyancsak vizsgálják a rendszerben rögzített adatok megfelelőségét. Az 1 éves utánkövetés során - amennyiben a beteg meghal - az NSZR számára megküldött sectiós adatokat az OEP fekvőbeteg-ellátási, illetve a KSH adatait használjuk a halálok megjelöléséhez.

\section{AMI-alapok miatt meghalt betegek száma: KSH-adatok}

A KSH adatai alapján a szívinfarktus miatt meghalt betegek száma folyamatosan csökken (1. ábra). Az 1993-as adatot $100 \%$-nak véve 2014 -ben mintegy $60 \%$-kal kevesebb beteg halt meg AMI-alapok következtében. A halálozási statisztika és a születéskor várható élettartam ada- 


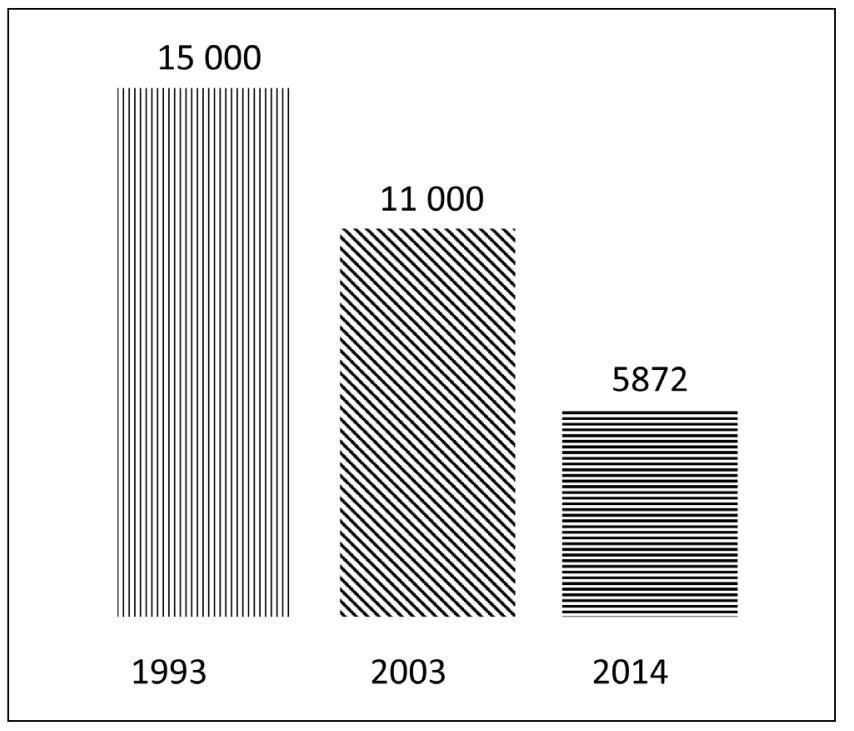

1. ábra $\quad$ AMI diagnózissal meghalt betegek száma - KSH

tait elemezve Józan [6] epidemiológiai korszakváltásról beszél, amelynek fő jellemzője a cardiovascularis halálozás jelentős - mintegy 35\%-os - csökkenése, amelynek legfontosabb összetevője, hogy a heveny szívinfarktus (AMI) halálozásának abszolút értéke 1993 és 2010 között 75,7\%o-kel csökkent. Az adatok elemzése azt is mutatta, hogy a krónikus ischaemiás szívbetegség miatt meghaltak aránya 38,2\%o-kel nőtt. Józan e nehezen értelmezhető jelenség további vizsgálatát tartotta szükségesnek. Vitrai és Bakacs [7] ugyanezen adatokat elemezve azt vetették fel, hogy az AMI-halálozás nem alkalmas indikátor a kardiológiai ellátás színvonalának mérésére, és részletes szakmai elemzések szükségesek ennek vizsgálatához.

\section{Az AMI 30 napos halálozása az OEP-adatok alapján}

Megvizsgáltuk az AMI halálozását az OEP úgynevezett finanszírozási adatbázisa alapján. 2013-ban az OEP adatai alapján 15343 betegnél szerepelt az ápolást indokló fódiagnózisként AMI (BNO 121-I23). A 30 napos utánkövetés során 2435 beteg halt meg (15,9\%). Amennyiben a betegeket két csoportra osztottuk és megkülönböztettük az AMI speciális kezelés nélküli csoportot (HBCS 2070) azoktól, akiknél koronarográfia, percutan intervenció, thrombolysis, illetve szívmütét történt. A betegek közel egyharmadánál $(30,1 \%)$ semmilyen speciális beavatkozásra nem került sor az infarktus kezelése kapcsán. A 30 napos halálozás a HBCS 2070-es csoportban $27,9 \%$ volt, míg a speciális beavatkozással kezelteknél a halálozás $10,7 \%$ volt.

\section{Az AMI 30 napos halálozása a Nemzeti Szívinfarktus Regiszter adatai alapján}

Az NSZR-ben 8254 infarktusos beteg adatai szerepelnek, ami az összes finanszírozott eset 53,7\%-a, akik közül a 30 napos utánkövetés során 937 beteg halt meg (11,4\%). A STEMI diagnózissal kezelt és regisztrált 4058 beteg $73 \%$-ánál történt primer percutan coronariaintervenció, míg a 4196 NSTEMI-beteg 50,5\%-ában történt katéteres érmegnyitás. Az infarktus típusa és a kezelés módja szerint észlelt 30 napos halálozási adatokat a 2. táblázatban tüntettük fel. Vizsgáltuk a jelentős különbség okát: az OEP-adatbázisban 1664 olyan meghalt infarktusos beteg szerepel, akikról a NSZR-ben nem találtunk adatot. Az 1664 beteg közül 858 beteg $(51,6 \%)$ vagy az otthonában, vagy úgynevezett egyéb (nem belgyógyászati, illetve kardiológiai) osztályon halt meg.

\section{Az AMI 30 napos halálozásának összehasonlítása az OEP és az NSZR adatai alapján}

Az adatok összehasonlítása első megközelítésben jelentős különbségre utal. Az OEP-adatbázisban a halálozás 15,9\%, míg az NSZR-ben 10,6\%. Az 5,3\%-os különbség jelentős. Lényegében megegyezik a két halálozási arány akkor, ha az OEP adatbázisában szereplő és speciális beavatkozásban részesült betegek csoportját vizsgáljuk, mert ezen betegcsoport 30 napos halálozása $10,7 \%$. Megvizsgáltuk továbbá, hogy az OEP-adatbázisban szereplő, de nem regisztrált és 30 napon belül meghalt 1664 beteg esetén hol következett be a halál. Azt találtuk, hogy 658 beteg $(39,5 \%)$ egyáltalán nem feküdt olyan osztályon, ahol a szívinfarktusos betegek ellátása történhet (kardiológiai, belgyógyászati, intenzív osztály). A halál bekövetkezésének a helye alapján (sebészet, neurológia, stroke-osztály, hematológia, ápolási osztály, krónikus osztály stb.) az látszik valószínünek, hogy a

2. táblázat | A STEMI és az NSTEMI diagnózissal kezelt betegek 30 napos halálozása

\begin{tabular}{lllll}
\hline & STEMI & STEMI+pPCI & NSTEMI \\
$\mathrm{N}=4058$ & $\mathrm{~N}=2956$ & $\mathrm{~N}=4196$ & $\mathrm{NSTEMI+PCI}$ \\
$\mathrm{N}$ 30 napos halálozás, $\%$ & 11,2 & 7,3 & 10 & 5,1 \\
\hline
\end{tabular}

NSTEMI = ST-elevációval nem járó myocardialis coronariaintervenció; $\mathrm{PCI}=$ percutan coronariaintervenció; pPCI = primer percutan coronariaintervenció; STEMI = ST-elevációval járó myocardialis infarctus. 
szívinfarktus nem az ápolást indokló fődiagnózis volt, hanem szövődmény. Az ápolást indokló fődiagnózis megjelölést finanszírozási szempontok indokolhatták. Amennyiben ezen betegektől eltekintünk, akkor 30 napos halálozás az OEP-adatbázisban 11,6\%, amely megegyezik az NSZR 11,4\%-os adatával.

\section{Következtetések}

Az OEP fekvőbeteg-adatbázisa a kórházi ellátás finanszírozásának szempontjait veszi figyelembe, nem alkalmas arra, hogy bizonyos betegségek halálozási arányát (case fatality ratio) vizsgálhassuk. A halálozási statisztika standardizált módszertana nemzetközi összehasonlítást tesz lehetővé, amelynek alapja a halottvizsgálati bizonyítvány megfelelő kitöltése. A halálozási statisztika fontos adat, de nem alkalmas az ellátás minőségének megítélésére. A betegségek kórlefolyásának, ellátásának és a minőségi paraméterek vizsgálatára betegregiszterek múködtetése szükséges. Magyarországon a Nemzeti Szívinfarktus Regiszter adatbázisa lehetővé teszi, hogy a betegek kórlefolyásáról, ellátásáról korrekt adatokkal rendelkezzünk. A hazai infarktusellátás vizsgálatakor ezen adatbázis használata javasolt.

Anyagi támogatás: A közlemény megírásához a szerzők anyagi támogatásban nem részesültek.

Szerzôi munkamegosztás: J. A.: A közlemény megtervezése és megírása. P. A.: A közleményben szereplő OEPanyagok összegyújtése és elemzése, a közlemény írásában való részvétel. Z. Á.: A közleményben szereplő KSH-adatok összegyújtése és elemzése. O. P.: A közlemény koncepciójának felvetése, az írásos anyag elkészítése. A cikk végleges változatát valamennyi szerző elolvasta és jóváhgyta.

Érdekeltségek: A szerzőknek a tanulmánnyal kapcsolatban nincsenek érdekeltségeik.

\section{Köszönetnyilvánítás}

A szerzők köszönik a KSH munkatársainak, Branyiczkiné Géczy Gabriellának, Bene Mónikának és Hilbert Lászlónénak, valamint Dr. Gresz Miklósnak, az Állami Egészségügyi Ellátó Központ szakértőjének a szíves együttmúködését.

\section{Irodalom}

[1] Gresz, M.: The paranoia of data collection in Hungary and the health system. [Az adatgyújtés paranoiája Magyarországon és az egészségügy.] Orv. Hetil., 2012, 153(29), 1158-1162. [Hungarian]

[2] Gresz, M.: Evaluating the National Health Insurance database of Hungary from the aspect of a health insurance specialist. [Az Országos Egészségbiztosítási Pénztár adatbázisa az egészségbiztosítási szakember szemével.] Orv. Hetil., 2012, 153(31), 1234-1239. [Hungarian]

[3] Häkkinen, U., Iversen, T., Peltola, M., et al.: Health care performance comparison using a disease-based approach: The EuroHOPE project. Health Policy, 2013, 112(1-2), 100-109.

[4] Edes, A.: Small money, large death: the end of the Hungarian legend. [Kis pénz, nagy halál: leszámoltak egy magyar legendával.] Heti Válasz, 2015. június 28. [Hungarian]

[5] Jánosi, A., Ofner, P., Merkely, B., et al.: Short and long term prognosis of patients with myocardial infarction. Hungarian Myocardial Infarction Registry. [Szívinfarktus miatt kezelt betegek korai és késői prognózisa. Magyar Infarktus Regiszter.] Orv. Hetil., 2013, 154(33), 1297-1302. [Hungarian]

[6] Józan, P.: New trend in mortality and life expectancy: the beginning of the fourth stage of epidemiologic transition in Hungary? [Fordulat a halandóságban és az életkilátásokban, epidemiológiai korszakváltás Magyarországon?] Orv. Hetil., 2003, 144(10), 451-460. [Hungarian]

[7] Vitrai, J., Bakacs, M.: Do they really save them? [Tényleg megmentik őket?] Lege Artis Medicinae, 2011, 21(11), 678-680. [Hungarian] 